\title{
Penerapan Metode Solfeggio Untuk Meningkatkan Minat Belajar Teori Dasar Musik Pada Siswa Kelas VII SMP Negeri 4 Jonggat Tahun Pelajaran 2019/2020
}

\author{
Sunardi \\ Guru Seni Budaya SMP Negeri 4 Jonggat
}

\begin{abstract}
Abstrak. Penelitian ini mengangkat masalah penerapan metode solfeggio untuk siswa kelas VII SMP Negeri 4 Jonggat. Peneliti menemukan bahwa di kelas VII SMP tidak diberikan materi tentang teori dasar musik yang salah satunya adalah solfeggio. Hal ini disebabkan karena tidak adanya materi tersebut didalam kurikulum 2013. Dalam meneliti masalah ini, peneliti merujuk kepada teori musik yang dikemukakan oleh Jamalus yang mengatakan bahwa kegiatan musik didasarkan pada dua kemampuan penting, yaitu penguasaan unsur-unsur musik dan faktorfaktor yang berhubungan dengan pendengaran. Kesimpulan dari penelitian ini adalah solfeggio merupakan salah satu teori dasar musik yang penting dan harus diberikan kepada siswa pada tingkat pertama. Karena tanpa bekal pengetahuan tentang solfeggio, siswa tidak akan punya kemampuan bermain musik yang baik. Materi ini bertujuan untuk mengembangkan kemampuan dasar musikal. Kemampuan ini meliputi kemampuan mendengar, kemampuan menirukan dan kemampuan membaca notasi musik.
\end{abstract}

\section{Kata kunci : Penerapan, Teori Dasar Musik, Solfeggio}

Abstract. This study rises the awareness towards the implementation of Solfeggio method in teaching 7th grade junior high school students, class VII SMP Negeri 4 Jonggat. Researcher found that music basic theory, solfeggio, was not part of the students' learning plan. This fenomenon was due to its absence in 2013 national curriculum. This study is framed with Jamalus music theory. The conclusion of this study is that solfeggio is one of important music basic theories that should be delivered in 7th graders-populated class due to its abillity in helping them to increase their musical skill. This theory is aimed to develop musical basic skill, such as, listening skill, copying skill, and music notes reading skill.

Keywords : Aplication, music basic theory, solfeggio

\section{PENDAHULUAN}

Pembelajaran seni musik adalah pembelajaran yang berusaha menggali dan mengembangkan potensi estetika siswa serta mempengaruhi siswa agar mempunyai nilai estetika sehingga dapat memperhalus budi pekerti, karena dalam seni terdapat unsurunsur keindahan, keteraturan, kedisiplinan dan dinamika. Melalui pendekatan "belajar dengan seni, belajar melalui seni, dan belajar tentang seni”, pembelajaran seni musik diberikan karena keunikan, kebermaknaan, dan kebermanfaatan terhadap perkembangan peserta didik berupa pemberian pengalaman estetik dalam bentuk kegiatan berekspresi atau berkreasi.

mampu

Pembelajaran seni musik diharapkan pemahaman, pengetahuan, pengalaman juga kemampuan berkarya seni agar siswa bisa berapresiasi terhadap budaya sendiri dan bisa menghargai orang lain yang pada akhirnya mereka bisa berperan aktif dalam kehidupan bermasyarakat, berbangsa dan bernegara.

$$
\text { Pembelajaran seni musik }
$$

merupakan salah satu pengembangan diri yang didalamnya dapat menggali dan mengembangkan keterampilan serta kreativitas perserta didik dalam bidang seni musik. Setiap anak memiliki potensi mendasar dalam bidang seni, termasuk seni musik. Potensi ini perlu dikembangkan dan ditanamkan sejak dini. Selain itu, keterampilan musik tidak dapat dipandang terpisah sebagai keterampilan seni music saja, melainkan juga sebagai satu kesatuan seni secara khusus dan umumnya sebagai keterampilan hidup (El Aziz, 2016 : 65). 
Pengembangan keterampilan ini bisa dilakukan melalui pembelajaran seni musik di sekolah. Karakteristik khas pendidikan

seni musik terletak pada keterampilan peserta didik yang diasahnya, yaitu rasa estetis dan artistik (Prastya, 2012). Meskipun terdapat keterampilan kognitif yang diajarkan, tetapi porsinya hanya sedikit dibandingkan dengan kedua keterampilan tersebut.

Salah satu kompetensi yang penting dalam pembelajaran seni musik adalah pengenalan nada. Peserta didik harus diajari bagaimana cara mengenal, membaca, dan memahami nada. Sehingga anak nantinya mempunyai kemampuan mengenali nada dan juga membaca notasi nada (Zhaang Hui, 2014). Sayangnya yang terjadi di lapangan adalah pembelajaran musik yang belum tepat. Contohnya adalah ketika guru mengajarkan bernyanyi kepada siswa hanya dengan imitasi saja, sehingga siswa hanya bisa 'membeo' gurunya tanpa bisa membaca nada ataupun mengenali nada (Puspita, 2016). Padahal Dalcroze menyatakan bahwa "tujuan pendidikan musik bukanlah untuk mencetak pemain musik atau penyanyi dengan teknik yang tinggi, melainkan untuk mengembangkan rasa musikal yang terdapat dalam diri manusia". Untuk itulah, pelatihan pendengaran adalah latihan yang paling penting dalam pembelajaran musik (El Aziz, 2016).

Bahan ajar yang bisa diberikan untuk melatih kepekaan pendengaran serta membaca dan menulis nada adalah solfeggio. Pada akhir pembelajaran diharapkan siswa dapat memiliki pemahaman mengenai dasardasar membaca dan menulis nada serta mempunyai kepekaan dalam membunyikan nada dengan baik untuk menunjang daya musikal. Dalam proses pembelajarannya, materi yang disampaikan adalah tentang keterampilan membaca notasi, menirukan bunyi, dan menulis notasi musik sederhana.

\section{KAJIAN PUSTAKA}

\section{A. Teori Dasar Musik}

Musik adalah bahasa emosi yang bersifat universal. Melalui pendengaran, musik dapat dimengerti dan dirasakan makna dan kesan yang terkandung didalamnya. Manusia normal sejak lahir sudah dibebani dengan kemampuan reaksi terhadap bunyi atau musik. Sehingga tanpa kegiatan mendengar, manusia tidak dapat memberikan reaksi terhadap rangsangan yang berbentuk bunyi (Puspita, 2016). Selanjutnya dikemukakan pula bahwa dalam mempelajari teori musik, harus diberikan melalui bunyinya, sehingga siswa dapat mendengar dan menghayati apa yang disebut dengan tangga nada, interval, melodi dan kord. Musik adalah rangkaian bunyi ekspresif yang disusun dengan maksud membangkitkan respons manusia (Prastya, 2012). Bunyi ekspresif disini mengandung makna suatu spektrum kemungkinan-kemungkinan yang luas dari nada, termasuk juga noise, dan kombinasinya dengan kesenyapan.

Pengertian lain menyatakan bahwa musik merupakan sarana yang dapat mengkomunikasikan sesuatu kepada pendengar (Prastya, 2012). Menurut Hoffman seperti dikutip oleh Prastya, (2012 : 38), sesuatu yang dikomunikasikan melalui musik yaitu ekspresi emosi. Hoffman juga menegaskan bahwa bunyi adalah bahan dasar keberadaan musik, musik adalah pengaturan bunyi.

Dari beberapa pengertian di atas dapat disimpulkan bahwa musik adalah salah satu media komunikasi yang bisa mewakili emosi setiap orang yang mendengarnya. Setiap rangkaian bunyi yang muncul menjadi sebuah musik dapat memberikan reaksi terhadap rangsangan yang dibeikan.

Hal pokok yang harus diperhatikan adalah bahwa aktivitas musikal melibatkan aspek pendengaran (auditif) sebagai dasarnya. (Rosmaniah, 2013 : 32), mengemukakan bahwa semua bentuk kegiatan musik memerlukan kemampuan mendengar, oleh karena itu kegiatan musik didasarkan pada dua kemampuan penting, yaitu penguasaan unsur-unsur musik dan faktor-faktor yang berhubungan dengan pendengaran. 


Berdasarkan beberapa
pengertian tersebut maka dapat
ditegaskan bahwa musik mempunyai cirri
- ciri : (1) adanya unsur bunyi, (2) adanya
pengorganisasian bunyi, dan (3) adanya
makna musikal.

Selain itu ada beberapa unsur music yang harus dipelajari dan dikuasai dengan baik diantaranya adalah suara, nada, ritme, notasi, melodi, dan harmoni. Teori musik menjelaskan bagaimana suara dinotasikan atau dituliskan dan bagaimana suara tersebut ditangkap dalam benak pendengarnya. Dalam musik, gelombang suara biasanya dibahas tidak dalam panjang gelombangnya maupun periodenya, melainkan dalam frekuensinya. Aspek-aspek dasar suara dalam musik biasanya dijelaskan dalam tala (pitch, yaitu tinggi nada), durasi (berapa lama suara ada), intensitas dan timbre atau warna bunyi (Njau, 2013).

Suara dapat dibagi-bagi ke dalam nada yang memiliki tinggi nada atau tala tertentu menurut frekuensinya ataupun menurut jarak relatif tinggi nada tersebut terhadap tinggi nada patokan. Perbedaan tala antara dua nada disebut sebagai interval. Nada dapat diatur dalam tangga nada yang berbedabeda. Tangga nada yang paling lazim adalah tangga nada mayor, tangga nada minor, dan tangga nada pentatonik. Nada dasar suatu karya musik menentukan frekuensi tiap nada dalam karya tersebut. Nada dalam teori music diatonis barat diidentifikasikan menjadi 12 nada yang masing-masing diberi nama yaitu nada C,D,E,F,G,A dan B. Serta nada-nada kromatis yaitu Cis/Des, Dis/Es, Fis/Ges, Gis/As, dan Ais/Bes.

Ritme adalah pengaturan bunyi dalam waktu. Birama merupakan pembagian kelompok ketukan dalam waktu. Tanda birama menunjukkan jumlah ketukan dalam birama dan not mana yang dihitung dan dianggap sebagai satu ketukan. Nada-nada tertentu dapat diaksentuasi dengan pemberian tekanan (dan pembedaan durasi) (Rosmaniah, 2013).

Notasi musik merupakan penggambaran tertulis atas musik. Dalam notasi balok, tinggi nada digambarkan secara vertikal sedangkan waktu (ritme) digambarkan secara horisontal. Kedua unsur tersebut membentuk paranada, disamping petunjuk-petunjuk nada dasar, tempo, dinamika, dan sebagainya. Bisa juga sebagai, symbol atau untuk menjelaskan tinggi dan rendahnya suara atau nada yang berbentuk sebuah gambar (Jamalus, 1988).

Melodi adalah serangkaian nada dalam waktu. Rangkaian tersebut dapat dibunyikan sendirian, yaitu tanpa iringan, atau dapat merupakan bagian dari rangkaian akord dalam waktu (biasanya merupakan rangkaian nada tertinggi dalam akord-akord tersebut). Melodi terbentuk dari sebuah rangkaian nada secara horizontal (Faisal Rahmat Permana, 2017). Unit terkecil dari melodi adalah Motif. Motif adalah tiga nada atau lebih yang memiliki maksud atau makna musikal. Gabungan dari motif adalah semi frase, dan gabungan dari semi frase adalah frase atau kalimat. Sebuah melodi yang paling umum biasanya terdiri dari dua semi frase yaitu kalimat tanya atau antisiden dan kalimat jawab atau onsekuen.

Harmoni secara umum dapat dikatakan sebagai kejadian dua atau lebih nada dengan tinggi berbeda dibunyikan bersamaan, walaupun harmoni juga dapat terjadi bila nada-nada tersebut dibunyikan berurutan (seperti dalam arpeggio). Harmoni yang terdiri dari tiga atau lebih nada yang dibunyikan bersamaan biasanya disebut akord.

\section{B. Solfeggio}

Dalam dunia musik dikenal suatu metode yang disebut Solfegio yaitu istilah yang mengacu pada menyanyikan tangga nada, interval dan latihan-latihan melodi dengan sillaby zolmization, yaitu menyanyikan nada musik dengan menggunakan suku kata (Puspita, 2016 : 154). 
Dalam perkembangan selanjutnya solfegio tidak hanya menyanyikan saja tetapi juga mendengar nada. Kemampuan membaca not disebut dengan istilah sight reading dan kemampuan mendengar not disebut dengan istilah ear training. Sight Reading merupakan membaca not tanpa persiapan (Puspita, 2016). Selanjutnya dinyatakan bahwa sight reading adalah kesanggupan sekaligus untuk membaca dan memainkan notasi musik yang belum pernah dikenal sebelumnya. Hal ini sering dinamakan dengan istilah prima vista.

Selain berfungsi untuk meningkatkan kemampuan membaca dan menambah pengetahuan tentang bahasa musik, sight reading juga berfungsi untuk menemukan hal-hal baru dalam musik dan memberikan kenikmatan dalam bermusik bagi pemain atau penyaji musik hingga pada tingkat ketrampilan (kemahiran) yang tinggi. Untuk dapat menguasai sight reading dibutuhkan banyak latihan yang teratur. Namun demikian bukan banyaknya latihan yang penting melainkan latihan-latihan (meskipun sedikit) yang dilakukan tiap hari secara teratur dan terus-menerus akan lebih dirasakan manfaatnya (Puspita, 2016 : 136). Ear training merupakan latihan kemampuan pendengaran atau ketajaman pendengaran musik, baik ketepatan ritmik maupun ketepatan nadanya. Kemampuan ini merupakan gabungan dari dua faktor, yaitu faktor kebiasaan dan pembawaan (Puspita, 2016 : 9). Faktor kebiasaan ini dapat dikembangkan melalui latihan teratur disamping faktor lain yang tidak dapat dipisahkan darinya yaitu faktor pembawaan dan musikalitas.

\section{METODE PENELITIAN}

Berdasarkan tingkat penjelasan dan bidang penelitian, maka jenis penelitian ini adalah penelitian deskriptif, yang merupakan jenis penelitian konklusif yang memiliki tujuan utama mendeskripsikan suatu karakteristik. Data yang diperoleh dalam penelitian ini merupakan data primer dan sekunder dari 27 orang siswa kelas VII SMP Negeri 4 Jonggat Tahun Pelajaran 2019/2020. Penelitian ini dilakukan untuk mengetahui apakah penerapan metode solfeggio dapat meningkatkan minat belajar siswa kelas VIIA untuk belajar teori dasar musik.

\section{HASIL PENELITIAN DAN PEMBAHASAN}

Tujuan pendidkan seni di SMP adalah agar peserta didik dapat berapresiasi dan berkreasi dibidang seni. Apresiasi berarti kegiatan mengartikan dan menyadari sepenuhnya seluk beluk karya seni menjadi sensitif terhadap gejala estetis sehingga mampu menikmati dan menilai karya karya tersebut secara semestinya. Sedangkan kreasi berarti mampu mengungkapkan perasaan estetis atau keindahan kedalam bentuk karya seni.

Hal pokok yang harus diperhatikan dalam pembelajaran seni musik adalah aktivitas musikal melibatkan aspek pendengaran (auditif) sebagai dasarnya. Karena semua bentuk kegiatan musik memerlukan kemampuan mendengar, oleh karena itu kegiatan musik didasarkan pada dua kemampuan penting, yaitu penguasaan unsur-unsur musik dan faktor-faktor yang berhubungan dengan pendengaran.

Berdasarkan hasil observasi yang dilaksanakan oleh peneliti sebelum tindakan dilaksanakan, menunjukan bahwa motivasi dan hasil belajar siswa dalam seni musik belum optimal. Ditandai dengan siswa tidak pernah membawa alat musik, kurang aktifnya siswa pada saat mengikuti palajaran seni musik, kurangnya penguasaan materi, kurangnya kerjasama antar siswa dalam kelompok. Hal tersebut dikarenakan guru masih menggunakan metode ceramah dimana guru mendominasi kegiatan pembelajara, namun siswa mengikuti secara pasif sehingga sebagian besar siswa kurang memahami teori dasar musik yang diberikan karena beberapa kemungkinan antara lain, (a) siswa kurang bisa menangkap apa yang dijelaskan oleh guru, (b) siswa belum bisa menguasai materi, dan (c) siswa belum dapat bekerjasama dengan baik dalam kelompok

Hal ini menyebabkan siswa menjadi cepat bosan dan bingung selama 
mengikuti kegiatan pembelajaran seni musik. Minat dan motivasi rendah sehingga hasil belajar yang diperoleh pun menjadi tidak maksimal. Oleh karena itu, guru perlu mengubah strategi dengan penerapan metode solfeggio untuk meningkatkan minat belajar teori dasar musik pada siswa kelas VII.

Setelah penerapan metode solfeggio terdapat peningkatan minat dan motivasi belajar musik siswa, ini terlihat dari siswa yang pada kegiatan awal pada saat mengikuti mata pelajaran seni musik tidak pernah membawa alat musik, setelah mengikuti pembelajaran ke dua menjadi bersemangat, mereka mulai mau membawa alat musik, itu menunjukan bahwa mereka mengalami peningkatan minat dan motivasi belajar.

Hasil belajar merupakan perilaku yang diperoleh pembelajar setelah mengalami proses belajar (Slameto.1991 : 5). Perolehan aspek-aspek perubahan perilaku tersebut tergantung pada apa yang dipelajari oleh pembelajar tersebut. Motivasi belajar menunjukan kepada hasil belajar, sedangkan hasil belajar itu merupakan indikator adanya derajat perubahan tingkah laku siswa (Slameto. 1991 : 59).

Dengan meningkatnya minat dan motivasi motivasi belajar musik siswa, hasil belajar juga akan meningkat. Dengan motivasi belajar yang meningkat akan sering terjadi interaksi pada saat jam pelajaran berlangsung, baik interaksi dengan guru ataupun interaksi antar siswa.

Dengan demikian penerapan metode solfeggio dapat meningkatkan minat dan motivasi belajar teori dasar musik pada siswa kelas VII SMP Negeri 4 Jonggat Tahun Pelajaran 2019/2020.

\section{KESIMPULAN}

Dari penjelasan di atas dapat disimpulkan bahwa teori dasar musik sangat penting untuk diberikan kepada siswa kelas VII SMP terutama diawal pembelajaran karena tanpa teori dasar musik yang kuat, siswa tidak akan mempunyai musikalitas yang baik. Salah satu teori dasar musik yang penting untuk diberikan adalah materi solfeggio. Karena tanpa bekal pengetahuan tentang solfeggio, siswa tidak akan punya kemampuan bermain musik yang baik. Materi ini bertujuan untuk mengembangkan kemampuan dasar musikal. Kemampuan ini meliputi kemampuan mendengar, kemampuan menirukan dan kemampuan membaca notasi musik.

SARAN

$\begin{array}{ccc}\text { Kepada } & \text { para guru seni musik } \\ \text { disarankan } & \text { untuk } & \text { memberikan }\end{array}$ pengetahuan dasar mengenai teori music kepada siswa agar para siswa bisa memiliki kemampuan musikal yang baik dengan diawali oleh pengetahuan dasar musik yang kuat.

\section{DAFTAR PUSTAKA}

El-Aziz, H. B. A. (2016). Extent Of The Effectiveness Of An Innovated Method To Teach Solfeggio Through Using Some Modern Methods. Journal Musical , 1(2), 32-40.

Faisal Rahmat Permana. (2017). Analisis Dokumen Perencanaan Mengajar pada Proses Belajar Piano Grade 1 di Elfamusic School Kopo Bandung. Universitas Pasundan.

Hardjana, 1983. Estetika Musik. Jakarta : Dirjen Dikdasmen.

Jamalus.1988. Pengajaran Musik Melalui Pengalaman Musik. Jakarta. CV Rajawali.

Njau, R. (2013). Penerapan Metode Drill Dalam Pembelajaran Seni Musik di Kelas XI IPA SMA Negeri 1 Tanjung Selor Kabupaten Bulungan.

Prastya, (2012). Proses Pembelajaran Musik Bagi Kelompok Band Sma Bopkri 1

Yogyakarta. Universitas Negeri Yogyakarta.

Puspita, P. S. (2016). Problematika Guru Non

Pendidikan Musik Dalam

Penyampaian Materi Pembelajaran Musik di SMP Negeri SeKabupaten Magelang. Universitas Negeri Yogyakarta.

Rosmaniah, S. M. (2013). Studi Tentang Kontrol Nada Dalam Pembelajaran Vokal Tingkat Dasar di Purwa Caraka Musik Studio. Cimahi. 
Siler, H. (2012). Toward An International Solfeggio. Journal of Research In Music Education, 4(1), 40.

Slameto.1991. Belajar dan Faktor-Faktor yang Mempengaruhinya. Bandung : Rhineka Cipta.

Yosep, W. (2014). Pembelajaran Musik Kreatif Pada Anak Usia Dini. Harmonia: Journal of Arts Research And Education, 5(1), 190-200.

Zhaang Hui. (2014). Solfeggio Class Teaching Method Inquisition. Journal of Ankang University, $1(1), 50-59$. 